\title{
The tornado of Talavera de la Reina on September 3, 1880
}

\author{
Víctor M.S. CARRASCO ${ }^{1,2 *}$, José M. VAQUERO ${ }^{2,3}$, Ángel BALLESTEROS ${ }^{4}$, \\ María CRUZ GALLEGO ${ }^{1,2}$ and José Agustín GARCÍA ${ }^{1,2}$ \\ ${ }^{1}$ Departamento de Física, Universidad de Extremadura, Avenida Elvas s/n, 06006 Badajoz, España. \\ ${ }^{2}$ Instituto Universitario de Investigación del Agua, Cambio Climático y Sostenibilidad (IACYS), Universidad de \\ Extremadura, Avenida de la Investigación s/n, 06006 Badajoz, España. \\ ${ }^{3}$ Departamento de Física, Universidad de Extremadura, Avenida Santa Teresa de Jornet 38, 06800 Mérida (Badajoz), \\ España. \\ ${ }^{4}$ Real Academia de Bellas Artes y Ciencias Históricas de Toledo, Calle de la Plata 20, 45001 Toledo, España. \\ * Corresponding author; email: vmscarrasco@unex.es
}

Received: February 7, 2020; accepted: June 9, 2020

\begin{abstract}
RESUMEN
El 3 de septiembre de 1880 un posible tornado ocasionó daños importantes en la ciudad de Talavera de la Reina (España). En este trabajo se analizan la descripción del fenómeno realizada por un observador de la época y las condiciones meteorológicas de aquel día. De acuerdo con nuestro análisis, la formación potencial de un tornado era posible. Éste sería el primer registro de la ocurrencia de un tornado en la región de Talavera de la Reina antes de 1975. De acuerdo con la descripción original, la intensidad del tornado podría clasificarse como EF2 según la escala Fujita mejorada.
\end{abstract}

\begin{abstract}
On September 3, 1880 a probable tornado caused significant damage in the city of Talavera de la Reina (Spain). In this work, we analyze the original description made by an observer of that time about this phenomenon and the meteorological conditions for that day. The potential formation of a tornado was possible according to our analysis. This would be the first record of a tornado in the region of Talavera de la Reina prior to 1975 . According to the original description, we could estimate the intensity of this tornado as EF2 (in the Enhanced Fujita Scale).
\end{abstract}

Keywords: meteorology, historical tornadoes, tornado climatology, Spanish historical data, Talavera de la Reina.

\section{Introduction}

Recent studies have shown that extreme weather events, such as tornadoes, are relatively frequent in Spain (Gayà, 2005; Riesco et al., 2015). The number of registered tornadoes has increased in recent decades with respect to past centuries. This fact, however, is not only related to meteorological factors, but also to changes in the perception of society about the importance of recording this type of phenomena (Verbout et al., 2006). For example, Gayà (2011) shows that a clear characteristic in the records of Spanish tornadoes prior to 1826 is that they were mainly registered in regions of Castile and Andalusia. Besides gathering the appropriate meteorological conditions for the tornado formation, these zones possessed a greater population and economic activity.

These events are of great interest due to their direct impact on society (Kunkel et al., 1999). The 
Enhanced Fujita Scale has been used since 2007 in order to characterize the strength of tornadoes according to the damage caused (Fujita, 1981; Texas Tech University, 2004; Riesco et al., 2015). This scale has six levels, from EF0 to EF5, representing the increase in the impact of damage. Tornadoes labeled as EF0 and EF1 are often referred as "weak", EF2 and EF3 as "strong", and those included in EF4 and EF5 as "violent". Thus, it is necessary to build a database that allows studying the frequency and meteorological characteristics of this kind of phenomena. In this work, we present and analyze the description of a probable tornado that occurred in Talavera de la Reina (Spain) in 1880. In section 2, we present the documentary source and the original description of the event. An analysis of this phenomenon is carried out in section 3. Main conclusions of this work are exposed in section 4 .

\section{Documentary source and description}

The title of an ancient manuscript written by the Jiménez de Castro family (from Talavera de la Reina) is Antigüedades de esta villa y otras varias (Antiquities of this villa and several others) (see Ballesteros, 2015). This work was started by José Jiménez de Castro in the 19th century and continued by his son Pedro, whose son Leopoldo stopped its writing in 1908. In 1957, Bernardo Jiménez de Castro y de la Cruz resumed it, indicating that neither his father Pedro nor his grandfather Bernardo wrote anything in the manuscript.

This book presents a collection of news articles from the 17th century onwards in the city of Talavera de la Reina, although several news articles of national interest were also collected. Different information as, for example, on the Basilica of Nuestra Señora del Prado, celebrations of the city, historical events, and descriptions about meteorological events can be consulted in this book. One of the meteorological events included in this documentary source is a probable tornado that crossed the city in 1880 causing significant damage. The following is the original description of this event: "El día 3 de Setiembre del mismo año [1880] hubo un huracán que duró como un minuto, hizo varios destrozos entre ellos fue arrancar varios árboles del Prado [Jardines] y la casa de madera del celador de consumos del puente del río fue volada al río y la varandilla y fue volado el tejado de $\mathrm{D}^{\mathrm{n}}$ Germán de la Maza y otros varios tejados de esta población" (Fig. 1) (On September 3 of the same year [1880], there was a hurricane that lasted about one minute, it made several damages, among them, to tear several trees from the Prado [Gardens] and the wooden house of the consumption guard of the river bridge and the railing was flown to the river, and the roof of Mr. Germán de la Maza and several other roofs of this city were flown).

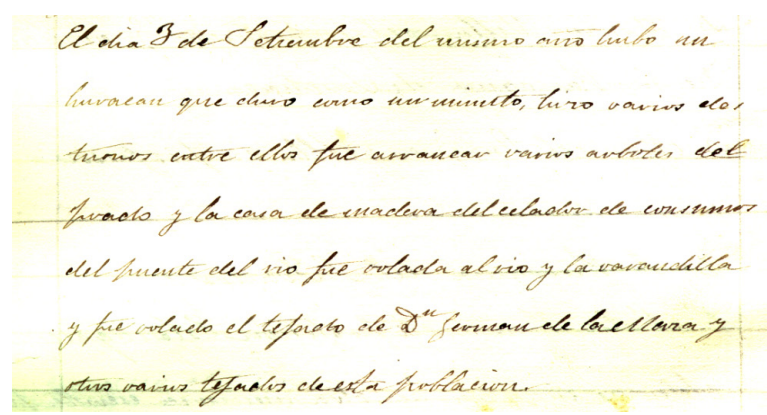

Fig. 1. Original description of the tornado of Talavera de la Reina occurred on September 3, 1880 included in Antigüedades de esta villa y otras varias (courtesy of the Basilica of Nuestra Señora del Prado).

\section{Analysis}

Talavera de la Reina $\left(39^{\circ} 58^{\prime} \mathrm{N}, 4^{\circ} 50^{\prime} \mathrm{W}\right)$ is a city located in the province of Toledo, belonging to the community of Castilla-La Mancha (Spain). Gayà (2011) elaborated on a database of historical tornadoes and no record of this type of meteorological event has been registered in the Talavera de la Reina area prior to 1975 (Fig. 2). Therefore, this case could be incorporated into this tornado database.

In the original documentary source, the meteorological term used to describe the event was "hurricane", which was usually employed in Spain to describe a very strong wind. Moreover, the description also indicates that the duration was approximately $1 \mathrm{~min}$. Thus, a tornado or a downburst are the meteorological events that best fit the description. We want to emphasize that the terminology used in the Spanish historical records to characterize this kind of meteorological event is not well defined. In fact, the Royal Academy of Spanish Language did not include the term "tornado" in its dictionary until 1884 (Gayà, 


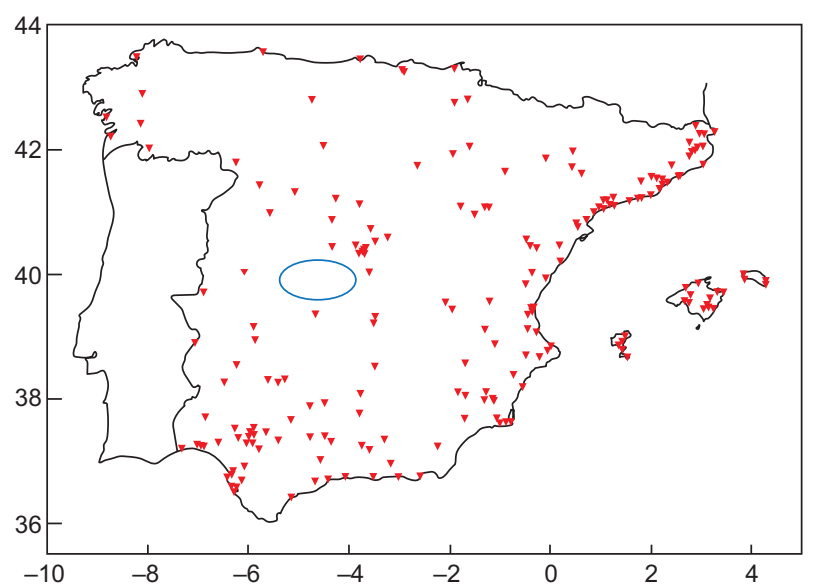

Fig. 2. Geographic distribution of tornadoes occurred in the period 1826-1975 (red triangles). The blue ellipse represents the location of the Talavera de la Reina area (source: Gayà, 2011).

2007). We also note that Lewis and Clark used the term "hurricane" in their journals for damage they observed during their expedition in the period (18031806), although that damage could be caused by some sort of high wind event (Preston, 2007).

According to the original description, among the damage caused by this extreme event, some trees felled in Jardines del Prado (Prado Gardens) and several roofs of the city were ripped. In addition, a railing and a wooden house were uprooted next to the bridge of the Tagus River. These facts increase the probability that it was a tornado. Furthermore, we can classify this event as a "probable tornado" following the categories defined by Rauhala et al. (2012). Thus, when we mention "tornado" in the text, it refers to this category of "probable tornado". In Figure 3, the approximate trajectory followed by the tornado is represented on a map of that time, in which the places mentioned in the text (with a current known location of the damages caused by the tornado) have been indicated: Jardines del Prado and the house of the consumption guard of the river bridge. Unfortunately, we do not know the exact location of the house of Mr. Germán de la Maza and all the houses mentioned in the original description that suffered damage. However, analyzing the known areas where this phenomenon had influence, we can confirm that, at least, the eastern half of the city was influenced (Fig. 3).

It is difficult to categorize this historical tornado according to the Enhanced Fujita Scale because we only have a textual report. Among the different damage indicators (DI) that are used to rate an event in

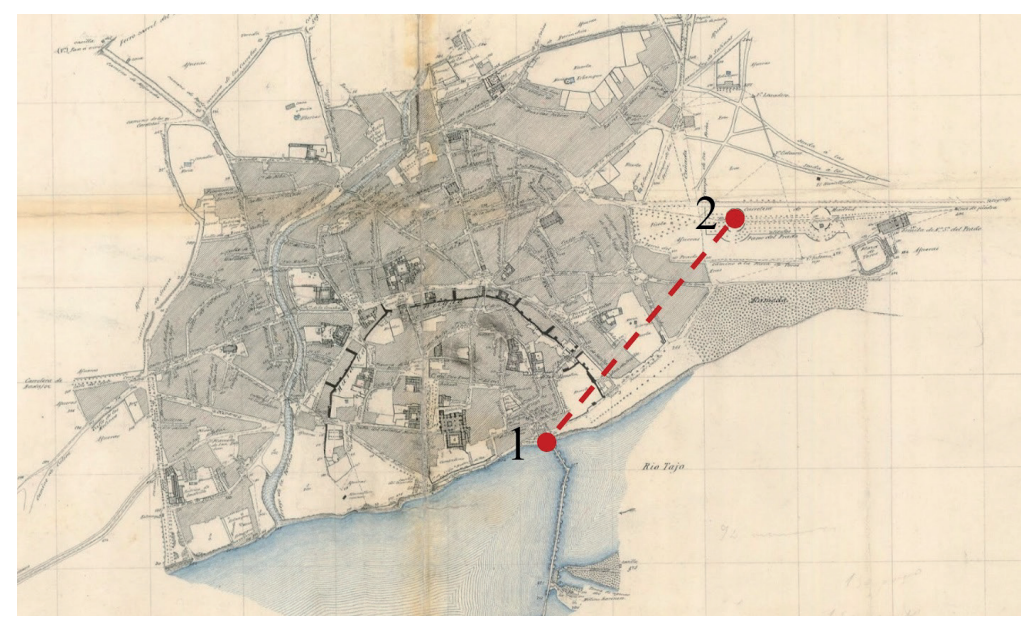

Fig. 3. Map of Talavera de la Reina dated in the 1880's (source: Centro Nacional de Información Geográfica, http://centrodedescargas.cnig.es/ CentroDescargas/index.jsp\#). Dots 1 and 2 represent the locations of the consumption guard of the Tagus river bridge and the Jardines del Prado, respectively, which are the two known places mentioned in the original description. Dashed line depicts the possible trajectory of the tornado. 
the Enhanced Fujita Scale (Texas Tech University, 2004), the damage reported in different houses of Talavera de la Reina could be identified to DI2, DI5, and DI7 and the uprooted trees to DI27 and DI28. For example, regarding DI2, the fact that large sections of roof structure were removed in several houses fits to the degree of damage number 6 , which is associated to wind speed equal to $196 \mathrm{~km} / \mathrm{h}$ (Texas Tech University, 2004). The recommended Enhanced Fujita Scale in this case would be EF2 (Texas Tech University, 2004). Considering DI27 and DI28, the uprooted trees in Jardines del Prado would indicate that at least we can associate it to wind speed of $210 \mathrm{~km} / \mathrm{h}$. Therefore, taking into account this analysis, we could estimate this tornado as EF2, which is within the tornadoes considered as strong (Texas Tech University, 2004; Riesco et al., 2015). This estimate would suppose that the intensity of the tornado occurred in Talavera de la Reina in 1880 would be less than in the historic Spanish tornadoes of Cádiz (1671) and Madrid (1886). In the old Fujita Scale, the tornadoes of Cádiz and Madrid were estimated as F4 (wind speed around 267-322 km/h) and F3 (wind speed around 219-266 km/h), respectively (Gayà, 2007, 2011). Unfortunately, these events caused deaths. While in Madrid the victim number was counted by tens, in the case of Cadiz it is not exactly known since documentary sources suggest that the number could range between several tens and more than six hundred (Sánchez-Laulhé, 2005).

Riesco et al. (2015) studied the climatology of 224 tornadoes recorded in the Iberian Peninsula and the Balearic Islands between 2003 and 2012. These authors exposed the typical meteorological conditions for the formation of tornadoes in the interior of the Iberian Peninsula. According to this study, the typical vertical profile of the peninsular interior is very dry at low levels during the summer, so the heating is very efficient. In the case of a significant cooling in middle layers, for example, with temperatures of $-12^{\circ}$ $\mathrm{C}$ in $500 \mathrm{hPa}$, large amounts of convective available potential energy (CAPE) can be developed and cause severe storms. These storms usually have relatively high bases, which limits the occurrence of tornadoes. However, if a tornado occurs, it can reach a high intensity (Riesco et al., 2015). A historical example of this type of meteorological events is the previously mentioned 1886 tornado of Madrid (Gayà, 2007).
In order to contextualize the synoptic conditions corresponding to the day of the tornado (September 3, 1880), Figure 4 shows maps for the European region regarding: (a) surface temperature, (b) temperature at $500 \mathrm{hPa}$, (c) mean sea-level pressure, (d) CAPE, (e) relative humidity at $1000 \mathrm{hPa}$, (f) $500 \mathrm{hPa}$, (g) specific humidity at $1000 \mathrm{hPa}$, (h) specific humidity at $500 \mathrm{hPa}$, and $(\mathrm{i}, \mathrm{k}) \mathrm{u}-\mathrm{v}$ components of wind speed at surface and $(\mathrm{j}, 1) 500 \mathrm{hPa}$. These maps were obtained from the online tool 20th Century Reanalysis V2c Data (Compo et al., 2011) provided by the National Oceanic and Atmospheric Administration (NOAA, http://www.esrl.noaa.gov/psd). Moreover, meteorological conditions on days of severe thunderstorm and tornado events can be highly variable between the morning and afternoon hours, therefore in those maps we have represented values from the reanalysis for the tornado day at 18:00 UTC. According to these reanalysis maps, for the tornado day, the mean sea-level pressure on the center of the Iberian Peninsula was around $1017 \mathrm{hPa}$. Although the original description does not mention anything about storm or raining, these phenomena usually accompany tornadoes. We obtained information about meteorological observations of precipitation for provincial capital cities next to Talavera de la Reina: Toledo (capital of the province where Talavera de la Reina is located) Cáceres, and Salamanca. The following news appeared in the Gaceta de Madrid (1880 [248, p. 750]), section Dirección General de Correos y Telégrafos: "Según los partes recibidos, ayer llovió en Almería, Cáceres, Pontevedra, Salamanca, Soria, Toledo y Valladolid" (English translation: According to the report received, yesterday it rained in Almería, Cáceres, Pontevedra, Salamanca, Soria, Toledo, and Valladolid) (Fig. 5a). Furthermore, observations about several meteorological variables made at the Madrid Observatory were also regularly published in the Gaceta de Madrid. We found that the maximum and minimum temperatures recorded at the Madrid Observatory on the tornado day (September 3, 1880) was 30 and $16.5^{\circ} \mathrm{C}$, respectively, with a measured precipitation of $0.5 \mathrm{~mm}$ (Fig. $5 \mathrm{~b}$, center panel). In the previous day (Fig. 5b, left panel), the maximum and minimum temperatures were 28.8 and $17.6{ }^{\circ} \mathrm{C}$ without precipitation $(0 \mathrm{~mm})$, and 28.3 and $15.8^{\circ} \mathrm{C}$ with $2.8 \mathrm{~mm}$ of precipitation for the following day after the tornado (Fig. 5b, right panel). Therefore, we 
lon: plotted from -20 to 45.00

lat: plotted from 30 to 80.00

t: Sep $3188018 \mathrm{Z}$

ev: o

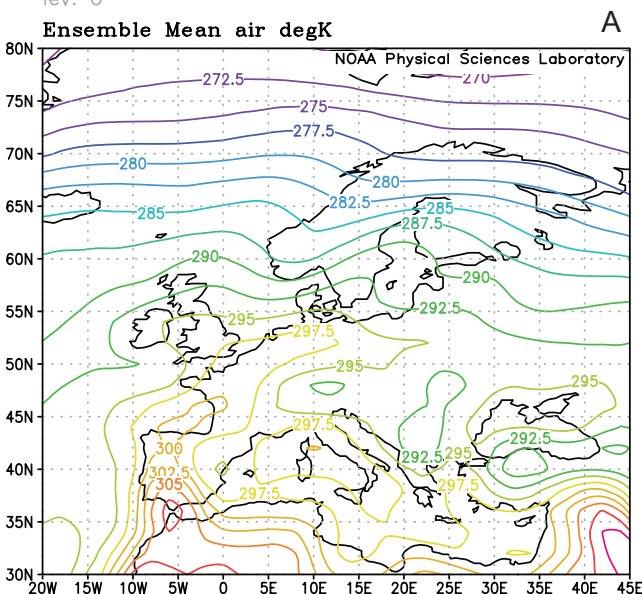

NOAA-CIRES $120 \%$ h Jentury Reanalysis version 2c GrADS image $\mathrm{MIN}=269$

lon: plotted from -20 to 45.00

lat: plotted from 30 to 80.00

t: Sep 3188018 Z

ev: 0

Ensemble Mean prmsl Pa

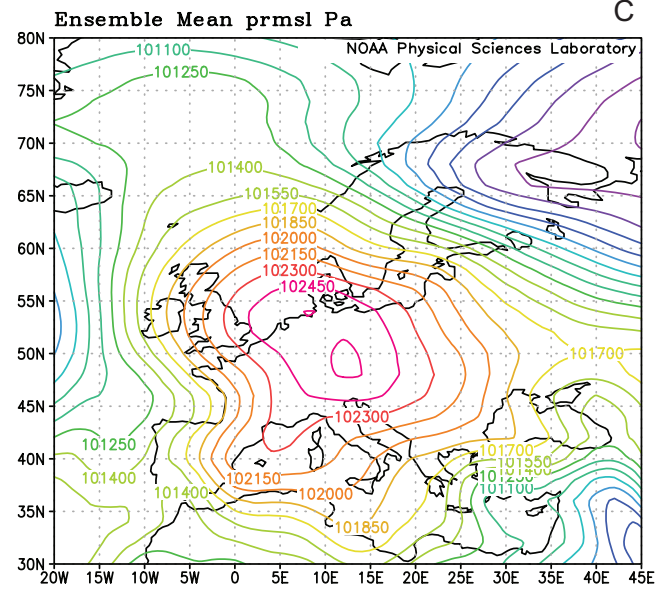

NOAA-CIRES $120 \%$ h Century Reanalysis version 2c GrADS image $\mathrm{MIN}=99867$

Ion: plotted from -20 to 45.00

lat: plotted from 30 to 80.00

lev: 1000

t: Sep 3188018 Z

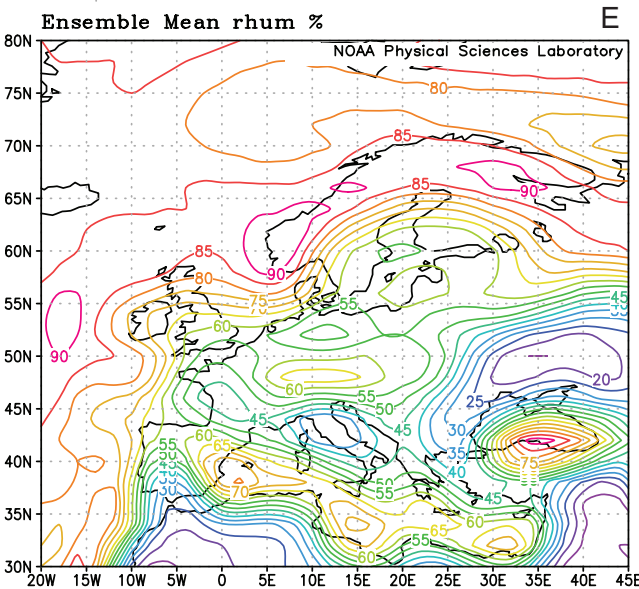
$M I N=10$

NOAA-CIRES $120 \%$ k Century Reanalysis version 2c GrADS image

$$
\text { 要 }
$$

sou

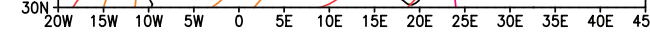

S $120 \%$ h Century Reanalysis version 2c GrADS image M $20 \mathrm{kh}$ Cientury
$M I N=244.4$

Ion: plotted from -20 to 45.00
lat: plotted from 30 to 80.00
t: Sep $3188018 \mathrm{Z}$
lev: 0

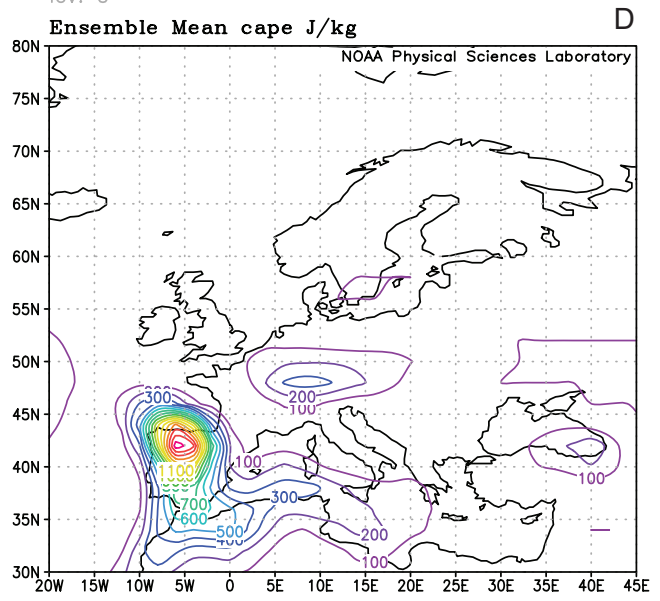

NOAA-CIRES $120 \%$ L 1 Cenitury Reanalysis version 2c GrADS image

$M I N=0$

lat: plotted from 30 to 80.00

lev: 500

t: Sep 3188018 Z

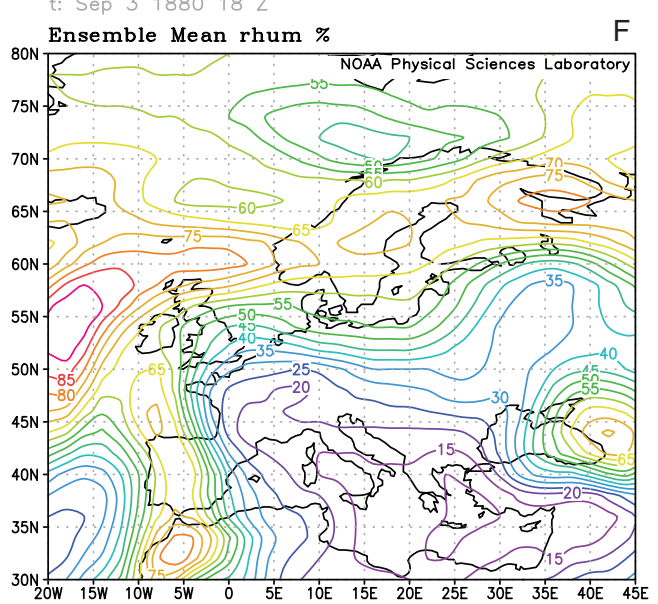
NOAA-CIRES $120 \mathrm{k}$ kCentury Reanalysis version 2c GrADS image

Fig. 4. Meteorological parameters for Europe on the tornado day (September 3, 1880) in Talavera de la Reina: (a) surface temperature; (b) temperature at $500 \mathrm{hPa}$; (c) mean sea-level pressure; (d) CAPE; (e, f) relative humidity at 1000 and $500 \mathrm{hPa}$, respectively; (g, h) specific humidity at 1000 and $500 \mathrm{hPa}$, respectively; (i, k) u-v components of wind speed at surface and (j, 1) $500 \mathrm{hPa}$, respectively. (Continue) 
Ion: plotted from -20 to 45.00

lat: plotted from 30 to 80.00

lev: 1000

t: Sep 3188018 Z

Ensemble Mean shum $\mathrm{kg} / \mathrm{kg}$

G

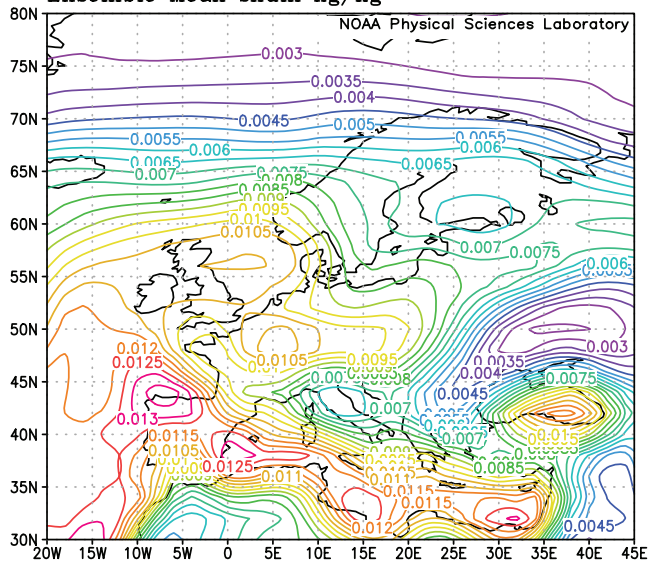

NOAA-CIRES $120 \%$ h Centūey Reanalysis version 2c GrADS image

Ion: plotted from -20 to 45.00

lat: plotted from 30 to 80.00

t: Sep 3188018 Z

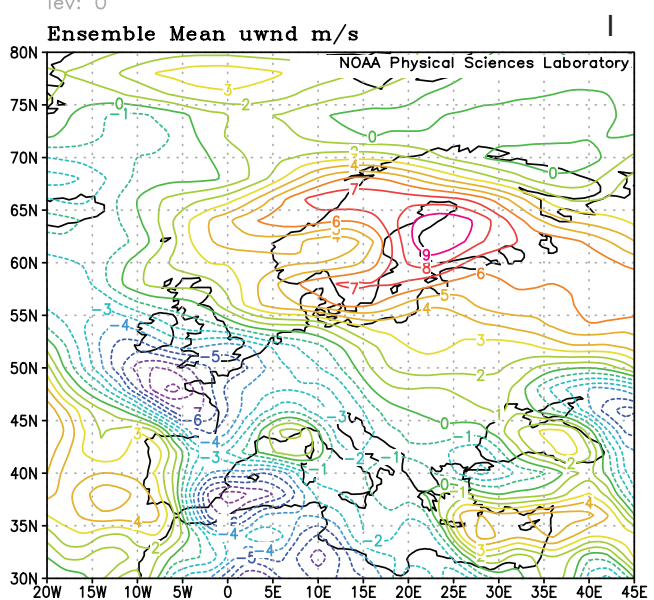

NOAA-CIRES $120 \mathrm{ck}$ CCentury Reanalysis version 2c GrADS image $\mathrm{MIN}=-9.4$

Ion: plotted from -20 to 45.00

lat: plotted from 30 to 80.00

t: Sep 3188018 Z

lev: 0

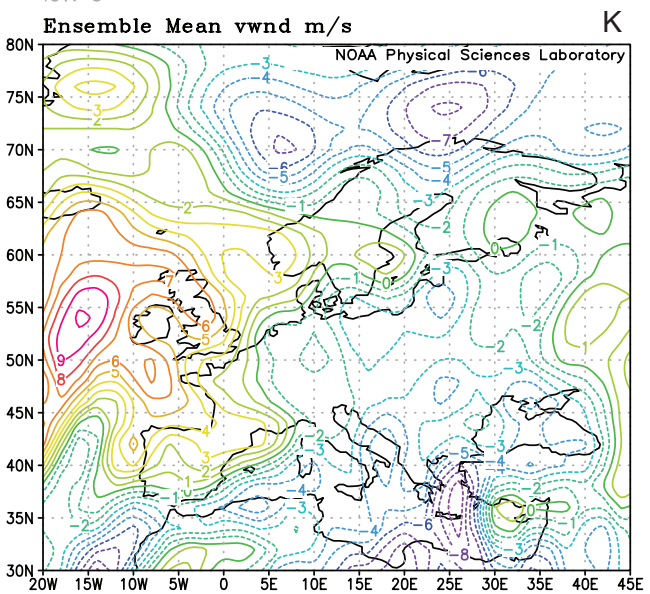

NOAA-CIRES 200 Ceñtury Reanalysis version 2c GrADS image $\mathrm{M} \mid \mathrm{N}=-9.9$ on: plotted from -20 to 45.00

lat: plotted from 30 to 80.00

t: Sep 3188018 Z

Ensemble Mean shum $\mathrm{kg} / \mathrm{kg}$

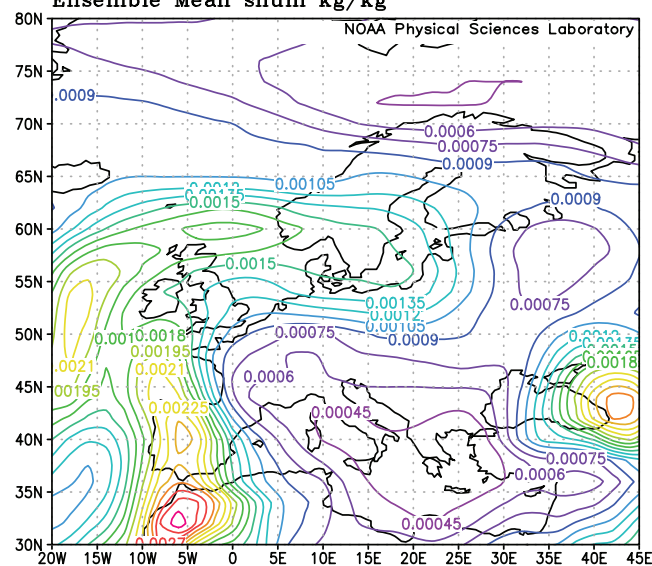

NOAA-CIRES $120 \%$ hCentúry Reanalysis version 2c GrADS image

$$
\begin{aligned}
& \text { lon: plotted from }-20 \text { to } 45.00 \\
& \text { lat: plotted from } 30 \text { to } 80.00 \\
& \text { lev: } 500.00
\end{aligned}
$$$$
\text { t: Sep } 3188018 \text { Z }
$$

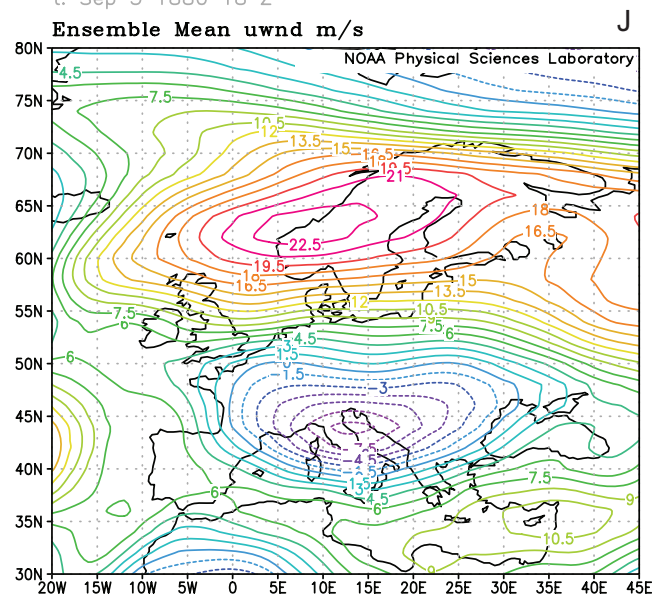

NOAA-CIRES $120 \%$ Century Reanalysis version 2c GrADS image $\mathrm{M} I \mathrm{~N}=-9.5$

Ion: plotted from -20 to 45.00

lat: plotted from 30 to 80.00

lev: 500.00

t: Sep 3188018 z

Ensemble Mean vwnd $\mathrm{m} / \mathrm{s}$

$\mathrm{L}$

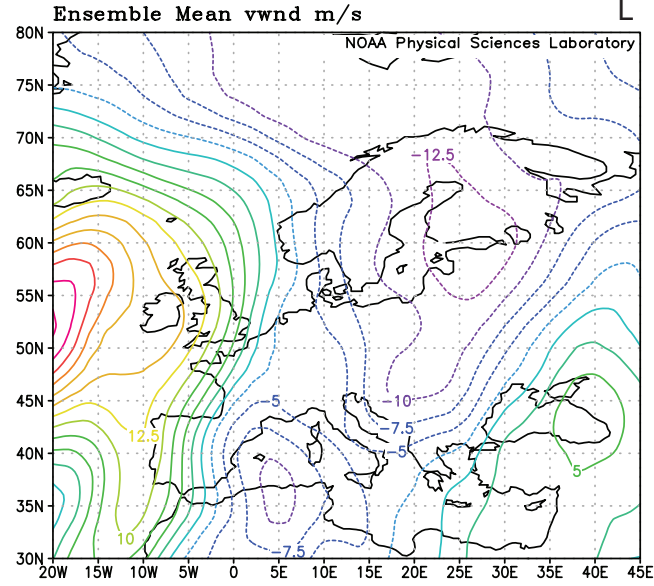

NOAA-CIRES $120 \%$ hentury Reanalysis version 2c GrADS image

Fig. 4. Meteorological parameters for Europe on the tornado day (September 3, 1880) in Talavera de la Reina: (a) surface temperature; (b) temperature at $500 \mathrm{hPa}$; (c) mean sea-level pressure; (d) CAPE; (e, f) relative humidity at 1000 and $500 \mathrm{hPa}$, respectively; (g, h) specific humidity at 1000 and $500 \mathrm{hPa}$, respectively; (i, k) u-v components of wind speed at surface and (j, 1) $500 \mathrm{hPa}$, respectively. 


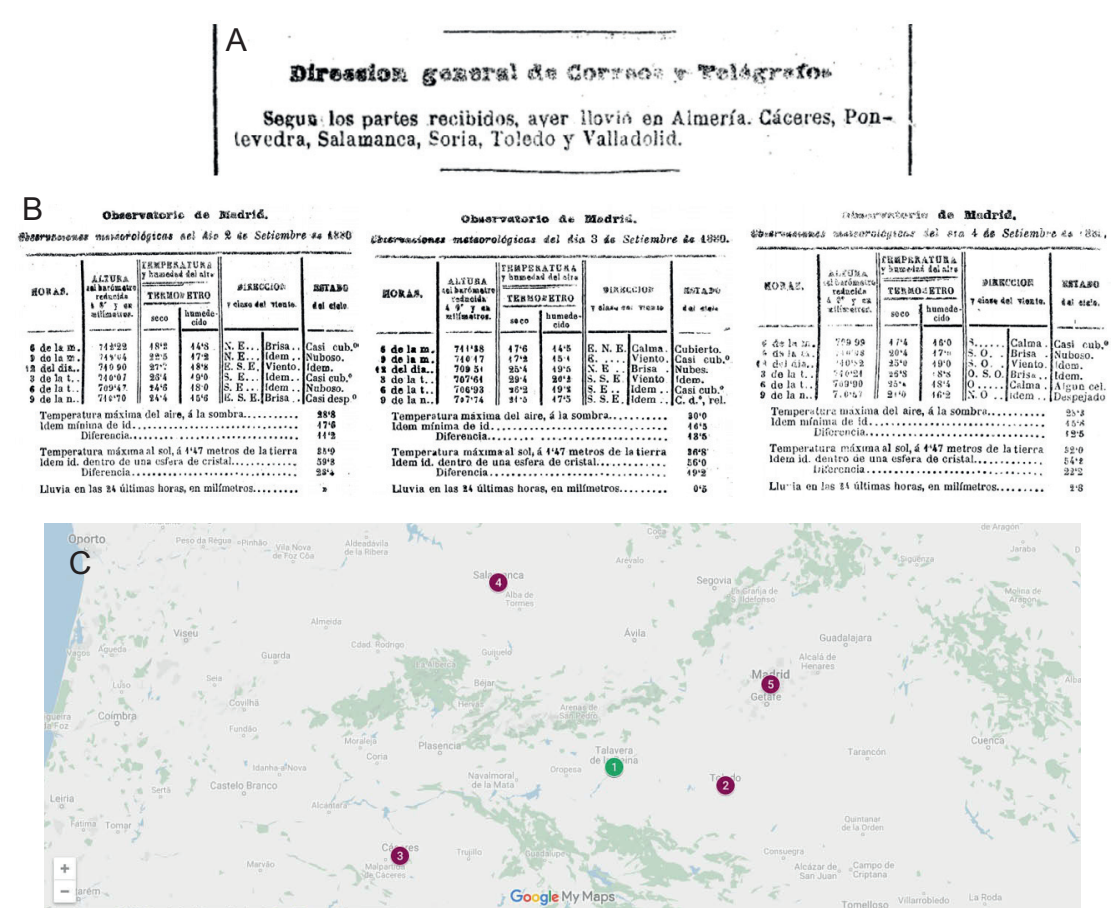

Fig. 5. (a) Reports of Spanish cities with raining conditions on the tornado day (source: Gaceta de Madrid, 1880 [248, p. 750]). (b) Meteorological observations made at the Madrid Observatory on September 2 (left), 3 (center), and 4 (right) 1880 (source: Gaceta de Madrid, 1880 [247, p. 738; 248, p. 750, and 249, p. 762]). (c) Locations of provincial capital cities next to Talavera de la Reina (1) where rainfall conditions were present on the tornado day: Toledo (2), Caceres (3), Salamanca (4), and Madrid (5).

found that it was raining in those cities during the tornado day, thus it probably also rained in Talavera de la Reina (Fig. 5).

In addition, according to the reanalysis maps, the surface temperature in Talavera de la Reina at 18:00 UTC was approximately $30{ }^{\circ} \mathrm{C}$ and about $-10{ }^{\circ} \mathrm{C}$ at $500 \mathrm{hPa}$, thus meeting one of the conditions established by Riesco et al. (2015) for the formation of tornadoes in the interior of the Iberian Peninsula. Regarding the surface temperature in Madrid for the tornado day, we highlight that data from the reanalysis (Fig. 4a) is in agreement with observational values (Fig. 5b). In Figure 4, it can be seen that the Iberian Peninsula is the only European region with a significant CAPE index for the day of the tornado. Specifically, in the area of Talavera de la Reina, the value of this index was approximately equal to $1100 \mathrm{~J} \mathrm{~kg}^{-1}$ on September 3, 1880. The maps show that relative humidity values in Talavera de la Reina were around $50 \%$ at $1000 \mathrm{hPa}$ and $65 \%$ at $500 \mathrm{hPa}$ for the tornado day. Furthermore, in general, the Iberian Peninsula had the greatest values for specific humidity in Europe both at $1000 \mathrm{hPa}$ and $500 \mathrm{hPa}$; therefore, it also met the condition of having enough available humidity for the formation of a tornado.

The 0-6 km bulk wind shear is used in severe convection researches (Monteverdi et al., 2003; Pilorz et al., 2016). This parameter is calculated by determining the difference in wind speed between the surface and at $6 \mathrm{~km}$ height (around $500 \mathrm{hPa}$ ). In order to estimate the bulk wind shear for the tornado day in the Talavera de la Reina area, we computed the wind speed (V) at surface and $500 \mathrm{hPa}$ from $u$ and $v$ components of wind speed obtained from reanalysis data (Fig. 4i-1), so that

$$
V=\sqrt{u^{2}+v^{2}}
$$

The wind speed value at surface is low (around $2 \mathrm{~m} \mathrm{~s}^{-1}$ ) and it would not be compatible with the 
formation of a tornado. Moreover, we have obtained a 0-6 km bulk wind shear value of roughly $4.7 \mathrm{~m} \mathrm{~s}^{-1}$, which we acknowledge is also low. For example, it would be around the 25th percentile found by Pilorz et al. (2016) for weak tornadoes recorded in Poland for the period 2011-2015. However, we highlight that the wind and shear in a particular place can undergo significant changes in minutes, which is hard to estimate for historical tornadoes. We also note that the wind speed in the $v$ component at surface and $500 \mathrm{hPa}$ is similar and no change in the direction of the wind can be found. However, we can see a change in the $u$ component. In this case, the wind speed increased from $-1 \mathrm{~m} \mathrm{~s}^{-1}$ (at surface) to $6 \mathrm{~m} \mathrm{~s}^{-1}(500 \mathrm{hPa})$ and, moreover, we can see that there is a change in the direction of the wind, because it blows from the east at surface and from the west at $500 \mathrm{hPa}$.

\section{Conclusions}

In this work we analyze the description of an extreme weather event that occurred in Talavera de la Reina $\left(39^{\circ} 58^{~ '} \mathrm{~N}, 4^{\circ} 50^{\prime} \mathrm{W}\right)$ in the year 1880 . In the historical catalogue of tornadoes in Spain carried out by Gayà (2011), no tornadoes had been recorded in the area of Talavera de la Reina before 1975. Therefore, this record could be incorporated into this historical database. Also, in a modern study by Riesco et al. (2015) for the period 2003-2012, no tornadoes were registered in the Talavera de la Reina region. It means that this zone is not a typical area for the appearance of tornadoes.

Although the event is defined as a hurricane in the original source, due to its short duration (approximately $1 \mathrm{~min}$ ) and the damage caused, the most likely meteorological event is a tornado. Furthermore, according to Rauhala et al. (2012), we can classify this event as a "probable tornado". The damage caused by this tornado consisted of the uprooting of several roofs of the city, in addition to a railing and a wooden house next to the Tagus River being teared off. Given this scenario, this tornado could be rated as EF2 according to the Enhanced Fujita Scale, which would mean that its wind gusts could have reached $179-218 \mathrm{~km} \mathrm{~h}^{-1}$. The maps of the meteorological variables obtained from the online tool 20th Century Reanalysis V2c data provided by NOAA, indicate that, on the tornado day, meteorological conditions in the area of Talavera de la Reina were: (a) surface temperature around $30^{\circ} \mathrm{C}$, (b) temperature at $500 \mathrm{hPa}$ around $-10{ }^{\circ} \mathrm{C}$, (c) mean sea-level pressure around $1017 \mathrm{hPa}$, (d) CAPE index approximately equal to $1100 \mathrm{~J} \mathrm{~kg}^{-1}$; (e) relative humidity at 1000 and 500 $\mathrm{hPa}$ of roughly 50 and $65 \%$, respectively, and (f) the greatest values of specific humidity in Europe. On the other hand, we have obtained low values of bulk wind shear with a significant change only in the $u$ component, but we acknowledge it is really hard to assess this variable for historical tornadoes because of the significant changes shear can undergo in minutes in a particular location. Furthermore, after consulting the meteorological observations for the provincial capital cities near Talavera de la Reina (Toledo, Cáceres, Salamanca, and Madrid) on the tornado day, we think that, although the original description does not indicate it explicitly, it rained in Talavera de la Reina since in those other cities that day was rainy. Thus, we can conclude that the synoptic situation analyzed in this work on September 3, 1880 in Talavera de la Reina adjusts to the conditions for the formation of a tornado.

Finally, we want to highlight the importance of knowing the frequency of these extreme events and the meteorological conditions for their formation. This information can help to reduce the damage caused by these phenomena. For this reason, it is important to continue improving the databases currently available and incorporating into them information relative to historical tornadoes.

\section{Acknowledgments}

This research was supported by the Consejo de Economía e Infraestructura of the Junta de Extremadura through project IB16127 and grant GR15137 (co-financed by the European Regional Development Fund) and by the Ministerio de Economía y Competitividad of the Spanish government (CGL201787917-P).

\section{References}

Ballesteros A. 2015. La Virgen del Prado. In: El libro de las antigüedades de la familia Jiménez de Castro (16691957). Archive of the Basílica de la Virgen del Prado de Talavera, Talavera de la Reina, Spain.Compo GP, 
Whitaker JS, Sardeshmukh PD, Matsui N, Allan RJ, Yin X, et al. 2011. The twentieth century reanalysis project. Quarterly Journal of the Royal Meteorological Society 137: 1-28. https://doi.org/10.1002/qj.776

Fujita TT. 1981. Tornadoes and downburst in the context of generalised planetary scales. Journal of Atmospheric Sciences 38: 1511-1534. https://doi.org/10.1175/1520 -0469(1981)038<1511:TADITC $>2.0 . C O ; 2$

Gaceta de Madrid. 1880. Dirección General de Correos y Telégrafos, 247 (p. 738), 248 (p. 750), 249 (p. 762).

Gayà M. 2005. Tornados en España (1987-2005): Distribución temporal y espacial. Revista de Climatología 5: 9-17.

Gayà M. 2007. The 1886 tornado of Madrid. Atmospheric Research 83: 201-210. https://doi.org/10.1016/j.atmosres.2005.10.017

Gayà M. 2011. Tornadoes and severe storms in Spain. Atmospheric Research 100: 334-343. https:/doi. org/10.1016/j.atmosres.2010.10.019

Kunkel KE, Pielke RA, Changnon SA. 1999. Temporal fluctuations in weather and climate extremes that cause economic and human health impacts: A review. Bulletin of the American Meteorological Society 80: 1077-1098. https://doi.org/10.1175/1520-0477(1999)080<1077:TFIWAC $>2.0 . \mathrm{CO} ; 2$

Monteverdi JP, Doswell CA, Lipari GS. 2003. Shear parameter thresholds for forecasting tornadic thunderstorms in northern and central California. Weather Forecasting 18: 357-370. https://doi.org/10.1175/15200434(2003)018<0357:SPTFFT > 2.0.CO;2
Pilorz W, Laskowski I, Lupikasza E, Taszarek M. 2016. Wind shear and the strength of severe convective phenomena-preliminary results from Poland in 2011-2015. Climate 4: 51. https://doi.org/10.3390/cli4040051

Preston V. 2007. Lewis and Clark: Weather and climate data from the expedition journals. American Meteorological Society Boston, USA, 544 p. 10.1007/978-0-933876-99-6Rauhala J, Brooks HE, Schultz DM. 2012. Tornado climatology of Finland. Monthly Weather Review 140: 1446-1456. https://doi. org/10.1175/MWR-D-11-00196.1

Riesco Martín J, Polvorinos F, Núñez Mora JA, Soriano Romero JD, Jiménez Alonso C. 2015. Climatología de tornados en España Peninsular y Baleares. Agencia Estatal de Meteorología, Ministerio de Agricultura, Alimentación y Medio Ambiente, Madrid, Spain, 83 pp.Sánchez-Laulhé JM. 2005. El tornado de Cádiz de 1671. Boletín de la Asociación Meteorológica Española 9: 11-15.

Texas Tech University. 2004. A recommendation for an Enhanced Fujita Scale (EF-Scale). Wind Science and Engineering Center, Texas Tech University Lubbok, Texas, USA.

Verbout, SM, Brooks HE, Leslie LM, Schultz DM. 2006. Evolution of the U.S. tornado database: 1954-2003. Weather and Forecasting 21: 86-93. https://doi. org/10.1175/WAF910.1 